time of $9.1 \mathrm{hr}$. at the south-west corner. The other two free waves have each an amplitude of $22 \mathrm{~cm}$. at the south-east corner, and the high-water time of the south-going Kelvin-wave at this point is $10.8 \mathrm{hr}$., and that of the north-going Poincaré-wave $0.5 \mathrm{hr}$. The agreement with observation is good as far as $5^{\circ} \mathrm{S}$. latitude, but considerable divergences set in afterwards. Part of this divergence may be due to not including a sufficient number of Poincaré-waves, and Prof. Proudman hopes to obtain better results by including more of these waves than he has done in the present investigations.

\section{PLANT DISEASE AND THE WEATHER}

\begin{abstract}
CLIMATE exerts an important influence on the 1 spread and severity of plant disease-an influence long recognized, though not yet fully investigated. Some recent progress in this field was discussed in a symposium arranged by the Department of Plant Pathology of the West of Scotland Agricultural College at Auchincruive on November 8. The meeting was attended by the edvisory pathologists for Scotland, the staff of the Plant Pathology Service of the Department of Agrieulture for Scotland, members of the College staff, of the University of Glasgow and the Hannah Dairy Research Institute.
\end{abstract}

Dr. C. E. Foister, head of the Plant Pathology Service of the Department of Agriculture for Scotland, opened by a short review of progress since the Conference of Empire Meteorologists in London in 1929. It becomes increasingly clear that records taken with ordinary meteorological exposure do not provide the pathologist with all the data he requires. It is necessary to study weather within the erop, and to follow up such information by investigations with artificially controlled conditions. Physiological races of fungi, moreover, may react differently to weather conditions. The distribution and occurrence of yellow rust of wheat in Scotland, for example, suggests the existence of different races varying in their reaction to environmental factors. Several parasitic fungi, common in England and Wales, are rare or unknown in Scotland, or confined to certain areas there. They include Puccinia triticina, Septoria tritici, Rhyneosporium secalis, Phytophthora cactorum, Diaporthe umbrina, Heteropatella antirrhini and the Dutch elm disease.

The rhododendron bug has twice invaded Scotland, but has failed to establish itself. How far are these apparent absences due to weather?

Dr. John Grainger, head of the Plant Pathology Department at Auchincruive, considered the aerial climate, the soil climate and the major effects of weather, with special reference to work carried out at Auchincruive in 1944. He showed how daily averages of aerial temperature and humidity inspired further work; but only continuous records within the crop revealed true phenological relationships. Chocolate spot of the field bean, bean leaf spot (Ascochyta fabce), and Erysiphe graminis on oats, all showed some increase of attack with rising relative humidity; but the real correlation was between disease intensity and the number of hours per day with complete saturation. Drain-gauge studies at Auchincruive have shown the large amount of rainfall evaporated from the soil. One aspect of aerial climate often neglected is that of conditions of storage for seed; it might be possible to provide conditions under which the parasites lose their viability before the seed. The major effects of weather are mainly important in so far as they transport fungal spores from one area to another. It has been found, however, that large teleutospores of some rust fungi are not carried more than a few yards by wind. Climate cannot, of course, be controlled, but the practical value of weather studies lies in the following points: (1) its value in lifehistory and mycological studies; (2) its help in raising immune or resistant erop varieties ; (3) virusinfected crops should be rogued within such temperature limits as the symptoms are not masked; (4) the time of farming operations can be adjusted to avoid some infections; (5) excessive atmospheric humidity may possibly be controlled in some parts of Scotland by adequate drainage; (6) conditions of seed storage may be devised to minimize seedborne disease; (7) growers may be advised when to spray in order to eliminate disease epidemics.

The role of weather as direct pathogen in causing frost damage to fruit blossom was discussed by Dr. C. E. Cornford, of the Midland Agricultural College. Field experiments with orchard heaters were described which showed that the hot air they supplied was chilled or warmed by several other agents. These included katabatic winds, altitude, the amount of cloud, the presence or absence of large dense grass exposed to the sky, the humidity of the air and the dryness of the trees and soil.

Dr. B. T. Cromwell (Auchincruive) presided over the discussion which followed. Mr. A. Heddle (Edinburgh) contrasted the epidemic of yellow rust in 1943 with its scarcity in 1944. The problem is complicated by the long growing-period of winter wheat. Dr. Mary Noble (Edinburgh) and Dr. Elizabeth Gray (Aberdeen) then contributed, and it appeared that winter wheat was generally much more susceptible than spring wheat in Scotland, and the severity of epidemics when they did occur was such that further detailed experiment was advisable. Dr. Grainger answered questions on frost damage in Dr. Cornford's absence. His own experience showed that oil heaters only raised the temperature of the air in their immediate neighbourhood by about $4^{\circ} \mathrm{F}$. Evaporation from the buds lowered their internal temperature by $2^{\circ} \mathrm{F}$., giving a net internal rise of about $2^{\circ} \mathrm{F}$. Trials with humidified heating raised the air temperature near the source by $2^{\circ} \mathrm{F}$., without internal cooling, thus resulting in a very considerable saving of fuel. Mr. Dovaston (Auchincruive) raised the question of avoiding grass cover in orchards subject to frost damage, but Dr. Cromwell and Mr. R. D. Reid (Auchincruive) held that grassing down was a very practical method of maintaining nutritional balance of the trees, particularly with regard to nitrogen.

Dr. Foister, Dr. Cromwell and Mr. Reid considered the oceurrence of Cladosporium mould in tomato glasshouses. The disease was often more severe in lowlying houses on sandy soil than in higher situations on heavy soil ; the factor of humidity did not seem to be the only one, and the admission of ultra-violet rays through 'Vita' glass did not eliminate the fungus. This discussion again pointed to the need for more detailed work. Dr. R. Laird (Ayrshire) mentioned that Ascochyta fabce and chocolate spot were more severe in low-lying, sheltered fields, but remembered that certain periods when these diseases were spreading were characterized by hot, dry days. Dr. Grainger explained, however, that long periods of complete 
saturation occurred during the nights at that timea fact which again stressed the value of continuous records within the crop. Dr. C. L. Whittles (Auchincruive) urged the necessity for continuous records of such soil factors as $p \mathrm{H}$, water content, conductivity and oxidation-reduction potential.

\section{INDUSTRIAL DEVELOPMENT IN AUSTRALIA}

$\mathrm{T}$ HE paper 'Scientific Aspects of Australia's Industrial Development", which Mr. G. B. Gresford read before the Royal Society of Arts on January 16, naturally covers a good deal of ground in common with the annual reports of the Commonwealth's Council for Scientific and Industrial Research, though the account is rather more up to date and in a larger setting. Mr. Gresford referred particularly to the recent plans of the Australian wool industry, stimulated no doubt by competition from artificial fibres, for a large expansion of scientific research. Part of the large sum which the Australian Wool Board proposes to raise by increasing the levy on growers of wool would be spent by the Council for Scientific and Industrial Research on biological and textile research, and part would go towards economic research and publicity. Whether or not the opinion is justified that fundamental research will lead to the improvement of wool yield and quality, the cheapening of processing and the development of new and novel fabrics so that wool can more than hold its own, the link between science and the wool industry will become closer.

After a reference to research in connexion with grain crops such as wheat, and the significance of the results in the field of nutrition and developments in the manufacture of fertilizers and sulphuric acid, $\mathrm{Mr}$. Gresford mentioned particularly the part science has played in the development of the mining and metal industries. Investigations on flotation, and particularly the discovery of the collecting properties of potassium ethyl xanthate for the sulphide minerals, have led to the present high recoveries of lead and silver in the flotation sections of the mines. The work at the University of Melbourne on fundamental physical chemistry of the flotation process, which for ten years before the War was financed by a group of Australian mining companies, is now partly earried on by the Council for Scientific and Industrial Research. Work in new fields has suggested possible extensions of the flotation process to the concentra. tion of new minerals. Mr. Gresford also referred to the continuous lead refining process for dressed smelter bullion evolved by the staff of the Broken Hill Associated Smelters as a striking example of the application of physical chemistry to an industrial process.

The paper industry, and particularly the development of processes for a wide range of papers from eucalyptus woods by a chemical or mechanical method, provides a further example of the solution by scientific research of a problem deemed intractable, and which has now made the Australian industry almost entirely independent of imported materials. Referring to the universities as sources of supply of scientific personnel for industry, Mr. Gresford said that the demand at present greatly exceeds the supply, and if maintained it will involve a corresponding expansion of the universities. Plans have been made for a considerable expansion of Government research activities, but further expansion of research in industry is desirable. So far, scientific exploration has not revealed any sources of flow oil in Australia; attention has not been given to the synthetic production of liquid fuels from coal, although the brown coal deposits of Victoria are very similar to those used in Germany for this purpose. Organic chemical industry on a large scale has scarcely been started and the development of the chemurgic industries, utilization of agricultural wastes, alkaloids and essential oils are other fields awaiting the application of scientific methods in Australia.

\section{SYNTHESIS OF BIOTIN}

A SYNTHESIS of biotin by S. A. Harris, D. E. A Wolf, R. Mozingo, R. C. Anderson, G. E. Arth, N. R. Easton, D. Heyl, A. N. Wilson and K. Folkers, of the Research Laboratory of Merck and Co., Inc., has recently been described (J.Amer. Chem. Soc., 66, 1756 ; 1944).

The process involves several steps: $l$-cystine is reduced in liquid ammonia with sodium and coupled with chloroacetic acid to give $\beta$-(carboxymethylmercapto)-alanine, subsequent benzoylation and esterification of which yielded the dimethyl ester of N-benzoyl- $\beta$-(carboxymethylmercapto)-alanine. The diethyl ester was obtained by condensing thioglycolic ester with the ethyl ester of $\mathrm{N}$-benzoyl- $\beta$-chloroalanine, 'derived from $\mathrm{N}$-benzoylserine by esterifica. tion and chlorination with thionyl chloride. The dimethyl ester was treated with sodium methoxide in methanol to give the radium salt of 4-benzamido3-ketotetrahydro-2-thiophenecarboxylic acid methyl ester, racemization occurring during the reaction. The sodium salt was hydrolysed and decarboxylated in an aqueous acetic acid - hydrochloric acid solution to give 4-benzamido-3-ketotetrahydrothiophene. The valeric acid side-chain was introduced by means of an aldehyde prepared from glutaric acid. The acid was converted in turn to glutaric anhydride, glutaric acid monomethyl ester, $\gamma$-carboxymethoxybutyryl chloride, and finally to methyl $\gamma$-formylbutyrate by a Rosenmund reduction.

The aldehyde ester, condensed with the ketone, 4-benzamido-3-ketotetrahydrothiophene, with piperidine acetate as catalyst, yielded the methyl ester of 4 - benzamido - 3 - keto - $\Delta^{2, \delta}$ - tetrahydro - 2 - thiophenevaleric acid, which reacted with hydroxylamine hydrochloride in pyridine to yield the methyl ester of 4-benzamido-3-oximino- $\Delta^{2, \delta}$ - tetrahydro- 2 - thio phenevaleric acid, reduction of which by zine dust in an acetic acid - acetic anhydride mixture gave two compounds, one the methyl ester of 3-acetamido4 - benzamido - 4,5 - dihydro - 2 - thiophenevaleric acid. Hydrogenation of this over a palladium catalyst and fractional crystallization of the products gave two racemates of the methyl ester of 3-acetamido-4benzamidotetrahydro-2-thiophenevaleric acid. Each of these was hydrolysed with barium hydroxide, and subsequent treatment of the products with sulphuric acid gave the corresponding sulphates of the 3,4diaminotetrahydro-2-thiophenevaleric acids.

The acids, when treated with phosgene, yielded two racemates of hexahydro-2-oxo-1-thieno[3,4] imidazole-4-valeric acid, which will be called dl-biotin, and $d l$-allobiotin. The $d l$-biotin was resolved through its esters with $l$-mandelic acid to give biotin. 